\title{
Perluasan Akses, Dukungan Kemitraan
}

\author{
Ismail Suardi Wekke \\ Dewan Pendidikan Kabupaten Maros \\ Email: iswekke@gmail.com
}

Assalamu Alaikum Warahmatulllahi Wabarakatuh

Bapak/Ibu, Saudara-saudari

Alhamdulillah, semoga nikmat kesehatan yang kita terima hari ini senantiasa membawa kita kepada aktivitas yang berkah.

Semoga Bapak/Ibu, saudara-saudari tetap sehat-sehat wal'afiat, di tengah suasana pandemi. Satu-dua sekolah di Jakarta, kembali ditutup. Seiring dengan merebaknya varian Omicron. Hanya saja, menurut saya ini perjalanan pandemi dimana varian semakin bertambah dengan daya gejala yang semakin ringan.

Sehingga suatu saat, akan semakin ringan. Dimana saat itu pula obat sudah ditemukan dan sudah dijual bebas dan murah sebagaimana obat flu hari ini. Sehingga ketika itu terjadi, kalaulah ada gejala, maka individu yang mengalaminya akan membeli obat dan karantina mandiri dengan istirahat.

Begitu pula dengan suasana kehidupan yang akan menggunakan lampu pandemi. Ketika merah, maka semua aktivitas dihentikan sementara, menunggu suasana menjadi kuning dan selanjutnya full aktivitas ketika hijau.

Bapak/Ibu, saudara-saudari. Namun bukan itu ketikan saya sepagi ini.

Hanya mengetikkan bahwa diskusi terkait belajar di UniSZA sudah terlaksana. Insya Allah secara bertahap akan kita wujudkan satu angkatan dimana belajar di UNISZA. Kita akan mengajak STAI DDI Maros dan perguruan tinggi lainnya untuk turut serta.

Walau, keputusan lembaga pimpinan tertinggi UniSZA tidak lagi memberlakukan potongan SPP. Namun, sebagaimana informasi dari Prof. Kamarul bahwa masih dapat dilakukan case by case. Untuk itu, saya akan melakukan diplomasi ke pimpinan dan juga senat UniSZA untuk memohonkan ini sehingga ada adek-adek kita ataupun juga dosen STAI DDI yang bisa didorong untuk kuliah.

Bapak/Ibu, saudara-saudari. Kenapa harus belajar ke luar negeri? Bagi saya, dengan belajar ke luar negara, akan memberikan perspektif yang bertambah. Tidak ada garansi lebih pintar ataupun lebih lainnya. Hanya saja, dengan belajar keluar negeri akan bertambah teman yang bisa saling membantu. Apalagi kaitannya dengan Maros yang dianugerahi Allah SWT dengan geopark.

Ini perlu dijadikan sebagai bagian dari promosi Maros. Sehingga kalaulah ada adek-adek yang studi lanjut ke luar negara, mereka akan menjadi duta kecil bagi Maros. Dimana orang yang sudah kenal Maros akan semakin kenal. Sementara yang belum kenal akan mengenal. 
Satu hal lagi, di Malaysia sendiri Maros itu bermakna nama keluarga. Saya bertemu dengan Prof Marlina Maros, saya bertanya ke beliau "apa artinya Maros, Prof?. beliau menjawab "itu tanah leluhur kakek saya". Setelah itu, saya belum bertemu lagi untuk berbincang soal Maros. Apakah Maros yang dimaksud itu adalah kabupaten Maros? Saya akan bertanya pada kesempatan selanjutnya.

Bapak/Ibu, Saudara-saudari.

Saya berpandangan bahwa Dewan Pendidikan Kabupaten Maros adalah fasilitator. Bukan badan eksekutif. Sehingga mengundang ataupun mengaak lembaga lain untuk mewujudkan program kerja Dewan Pendidikan, adalah sebuah keperluan. Sehingga fungsi-fungsi fasilitator tadi dapat terwujud.

Dalam kaitan dengan perluasan akses belajar ke luar negeri ini, kita bisa mengajak STAI DDI Maros, dan perguruan tinggi lainnya. Dimana melalui perguruan tinggi ini, kemitraan untuk menyediakan akses belajar ke luar negeri dapat kita aktualisasikan. Sebagaimana tema rapat kerja di bulan Desember yang lalu.

Selamat beraktivitas hari ini, Bapak/Ibu, Saudara-saudari. Semoga senantiasa dilimpahkan kemudahan dan keberkahan.

Saya juga menggunakan kesempatan ini menyampaikan kepada saudara kita, selessureng malebbitta ustadz Rahmat. Selamat mengemban amanah sebagai Wakil Ketua III STAI DDI Maros. Semoga amanah ini menjadi washilah bagi kemanfaatan untuk warga Maros dan kita semua.

Wassalamu Alaikum Warahmatullahi Wabarakatuh

Jakarta, 19 Januari 2022 